\title{
Analysis of land use changes to the criticality level of the catchment area in eight watersheds that flow into Jakarta Bay, Indonesia
}

\author{
Fitriyanto Bobby Rachmat ${ }^{1,3^{*}}$, Helmi Muhammad ${ }^{2,3}$ \\ ${ }^{1}$ Master Program in Environmental Science, Universitas Diponegoro, Semarang - Indonesia \\ ${ }^{2}$ Faculty of Fisheries and Marine Science, Universitas Diponegoro, Semarang - Indonesia \\ ${ }^{3}$ Center for Coastal Rehabilitation and Disaster Mitigation Studies, Universitas Diponegoro, Semarang - Indonesia
}

\begin{abstract}
Environmental problems in Jakarta, especially flooding problem, is strongly influenced by the condition of eight watersheds that flow into Jakarta Bay, namely Bekasi, Cisadane, Angke Pesanggrahan, Ciliwung, Krukut, Cakung, Buaran and Sunter. The center-periphery relationship between Jakarta and surrounding areas triggered significant land use changes in the watershed, especially in the upstream area. This study aims to analyze land use changes in eight watersheds that flow into Jakarta Bay in 2000, 2009 and 2017 as well as their effect on the distribution of the criticality level of the catchment area, using Geographic Information System (GIS) refers to Planning Procedures for Forest and Land Rehabilitation Engineering Watershed. The criticality map of the catchment area was created by overlay and scoring slope infiltration map, soil infiltration map and rainfall infiltration map. The results showed that there was a significant increase in built-up area of $14,33 \%$ in $2000-2009$ and $10,42 \%$ in $2009-2017$. In contrast, the area of dry land farming decreased significantly by $12,99 \%$ in $2000-2009$ and $5.96 \%$ in $2009-2017$. Based on the criticality analysis of the catchment area, land use changes in study area, mainly due to urban growth, has a significant effect on the criticality level of the catchment area.
\end{abstract}

Keywords: watershed; land use changes; catchment area

\section{Introduction}

Jakarta, the capital city of Indonesia, became one of the fastest growing metropolitan cities in the world. Jakarta's strong economic growth becomes a magnet for Indonesians to live and earn a living in Jakarta. Based on data from BPS DKI Jakarta Province (2018), the population of Jakarta in 2016 reached 10,28 million people. It then increased to 10,37 million by 2017 [1]. The increasing population in Jakarta demands the availability of space and land for housing and business needs. As a result, Jakarta metropolitan city spatially grows out of the administrative area of Jakarta to the surrounding areas in West Java and Banten.

The economic development of a city, as the condition of Jakarta, is able to trigger unplanned urban growth up to the upstream area, to accommodate population growth [2]. Such urban development is generally termed as Urban Sprawl. Land-use changes due to urban sprawl have a negative impact on the environmental and socioeconomics [3].
Jakarta has thirteen rivers flowing into Jakarta Bay. The condition of these rivers is strongly influenced by the hydrological characteristics of eight watersheds that shelter them. The urban sprawl phenomenon encourages land use changes in all areas adjacent to Jakarta, where some of these areas are the upstream areas of eight watersheds that flow into Jakarta Bay. These conditions make flood disaster occur in Jakarta almost every year. Changes in land use, especially vegetation, degrade water catchment quality due to disruption of rainfall infiltration process [4].

This study aims to analyze land use changes in eight watersheds that flow into Jakarta Bay in 2000, 2009 and 2017 and their effect on the criticality level of the catchment area. The results of this study are expected to be a supporting material in the formulation of policies to address flood and spatial problems in Jakarta and surrounding areas. We believe that good regional management policies can create sustainable low-carbon urban development

\footnotetext{
*Corresponding author: bobby.kemenhut@gmail.com
} 


\section{Study Area}

The study was conducted in eight watersheds that flow into Jakarta Bay with a total area of $\pm 443.314,50$ Ha. The eight watersheds are Bekasi, Cisadane, Angke Pesanggrahan, Ciliwung, Krukut, Cakung, Buaran and Sunter. Astronomically, the study area is located at $06^{\circ}$ $00^{\prime} 14.8$ " $-06^{\circ} 47^{\prime} 17.9^{\prime \prime}$ South Latitude and $106^{\circ} 28^{\prime} 53.5$ "- $107^{\circ} 13^{\prime} 6.6^{\prime \prime}$ East Longitude. Based on the administrative boundary data from Geospatial Information Agency (BIG), the study area is located in 3 Province and 14 districts/cities.

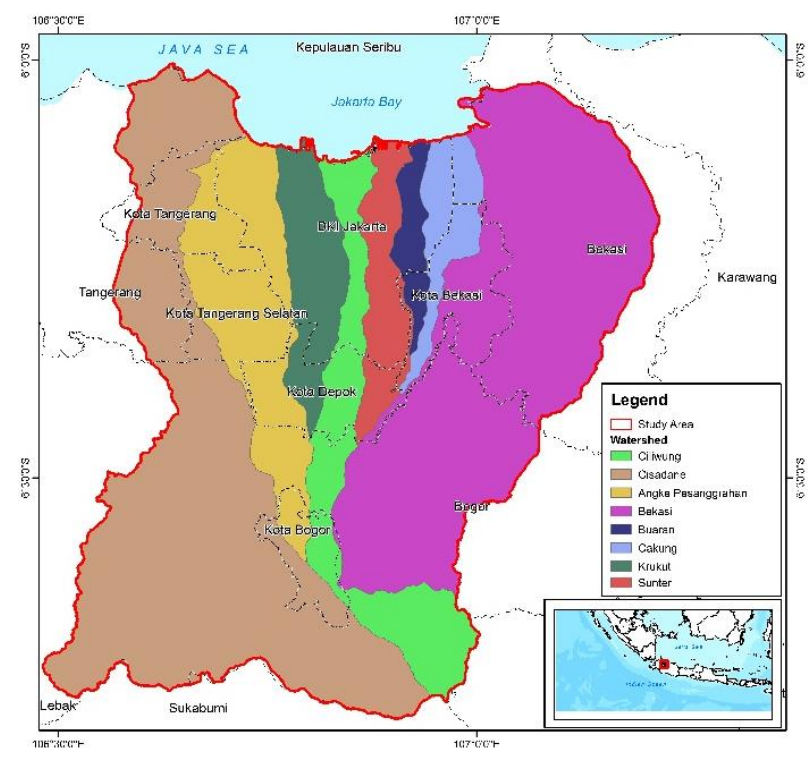

Fig 1. Study area Map

\section{Data and Methods.}

The data used in this study are land use data of 2000 , 2009 and 2017 sourced from the Ministry of Environment and Forestry, Soil Hydrology Group data sourced from Report of Detailed Flood Handling Preparation Plan in Jabodetabekjur [5], slopes data processed from Digital Elevation Model (DEM) ALOS Digital Surface Model (DSM) with 12.5 meters resolution and rainfall data sourced from Meteorology and Geophysics Agency (BMKG). Rainfall data was processed into rainfall map with Inverse Distance Weighted (IDW) method.

In this study, the method for find out the criticality levels of the catchment area was using Planning Procedures for Forest and Land Rehabilitation Engineering Watershed by Ministry of Forestry, Republic of Indonesia refer to P.32/Menhut-II/2009, through overlay and scoring potential infiltration map (rainfall infiltration, slope infiltration, soil infiltration) and actual infiltration map (land use map) [6]. According to Dong et al., (2015), slopes, soils, rainfall and forest cover are the main variables that influence the process of rainfall infiltration.

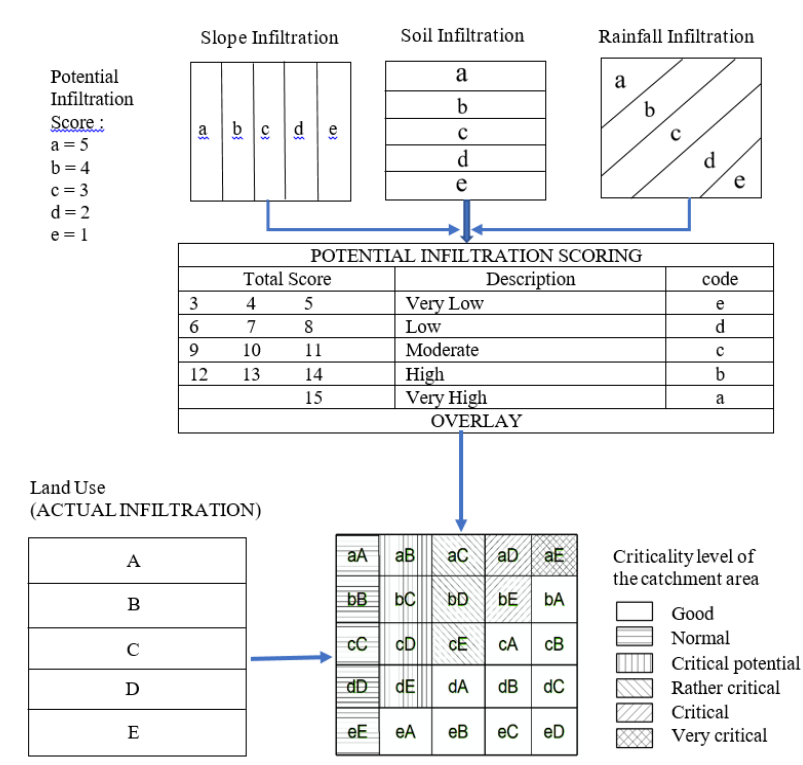

Fig 2. Criticality analysis of the catchment area Source : P.32/Menhut-II/2009

\section{Results and Discussion}

\subsection{Land use changes}

The land use data in this study is sourced from the Ministry of Environment and Forestry. This data was obtained from the interpretation of Landsat satellite imagery ( 30 meter resolution) that has been tested for accuracy. The results showed that the built up area increased significantly, i.e., 63.509 Ha from 2000 to 2009 and 46.181 Ha from 2009 to 2017. Meanwhile, the area of dry land farming decreased significantly, i.e., 57.579 Ha from 2000 to 2009 and 26.435 Ha from 2009 to 2017. The large-scale conversion of dry land farming into built up area indicates that there was a transformation of the socio-economic structure in peri-urban areas from ruraldominated activities to more urban activity [7].

\subsection{Rainfall}

The rainfall data required in this study is the total annual rainfall and total rainy days. Both data are used to obtain the value of Rainfall Infiltration (RD), through the formula:

$R D=($ total annual rainfall $x$ total rainy days $) / 100$

Rainfall data in this study is the average of rainfall from 2000 to 2017 in seven weather stations located in the study area. Based on homogeneity test results, rainfall data in this study is homogeneous data so it can be used as a reference. Trend of Rainfall Infiltration values from 2000 to 2017 in seven weather stations shows that the largest RD values occurred in 2010 while the lowest RD values occurred in 2015. Fluctuations in $R D$ values is influenced by extreme weather phenomena, especially La Nina that occurred in 2010 and the El Nino that occurred in 2015 . 
Table 1. Area statistics of the land use classes of 2000, 2009 and 2017

\begin{tabular}{|c|c|c|c|c|c|c|c|c|}
\hline \multirow[b]{2}{*}{ No } & \multirow[b]{2}{*}{ Landuse Classes } & \multirow[b]{2}{*}{$\begin{array}{c}\text { Infiltration } \\
\text { Code }\end{array}$} & \multicolumn{2}{|c|}{2000} & \multicolumn{2}{|c|}{2009} & \multicolumn{2}{|c|}{2017} \\
\hline & & & Area (Ha) & $\begin{array}{c}\text { Area } \\
(\%)\end{array}$ & Area (Ha) & $\begin{array}{c}\text { Area } \\
(\%)\end{array}$ & Area (Ha) & $\begin{array}{c}\text { Area } \\
(\%)\end{array}$ \\
\hline 1 & Primary forest & A & $1.192,92$ & 0,27 & $1.192,92$ & 0,27 & $1.155,28$ & 0,26 \\
\hline 2 & Secondary forest & A & $20.413,23$ & 4,60 & $18.823,14$ & 4,25 & $20.596,48$ & 4,65 \\
\hline 3 & Plantation forest & $\mathrm{B}$ & $14.693,36$ & 3,31 & $16.944,70$ & 3,82 & $11.600,40$ & 2,62 \\
\hline 4 & Scrub & $\mathrm{C}$ & $4.732,79$ & 1,07 & $4.532,18$ & 1,02 & 266,47 & 0,06 \\
\hline 5 & Plantation & $\mathrm{B}$ & $11.721,72$ & 2,64 & $10.376,18$ & 2,34 & $6.360,56$ & 1,43 \\
\hline 6 & Built up area & $\mathbf{E}$ & $98.495,13$ & 22,22 & $162.004,99$ & 36,54 & $208.186,53$ & 46,96 \\
\hline 7 & Bare soil & $\mathrm{E}$ & $3.754,04$ & 0,85 & $1.155,27$ & 0,26 & $1.367,15$ & 0,31 \\
\hline 8 & Water body & - & $1.891,99$ & 0,43 & $1.882,27$ & 0,42 & $2.020,25$ & 0,46 \\
\hline 9 & Dry land farming & D & 178.156,91 & 40,19 & $120.577,09$ & 27,20 & $94.141,74$ & 21,24 \\
\hline 10 & Paddy field & $\mathrm{E}$ & $102.590,37$ & 23,14 & $100.153,72$ & 22,59 & $91.951,61$ & 20,74 \\
\hline 11 & Coastal fishpond & $\mathrm{E}$ & $5.672,03$ & 1,28 & $5.672,03$ & 1,28 & $5.668,01$ & 1,28 \\
\hline & Total & & $443.314,50$ & 100 & $443.314,50$ & 100 & $443.314,50$ & 100 \\
\hline
\end{tabular}

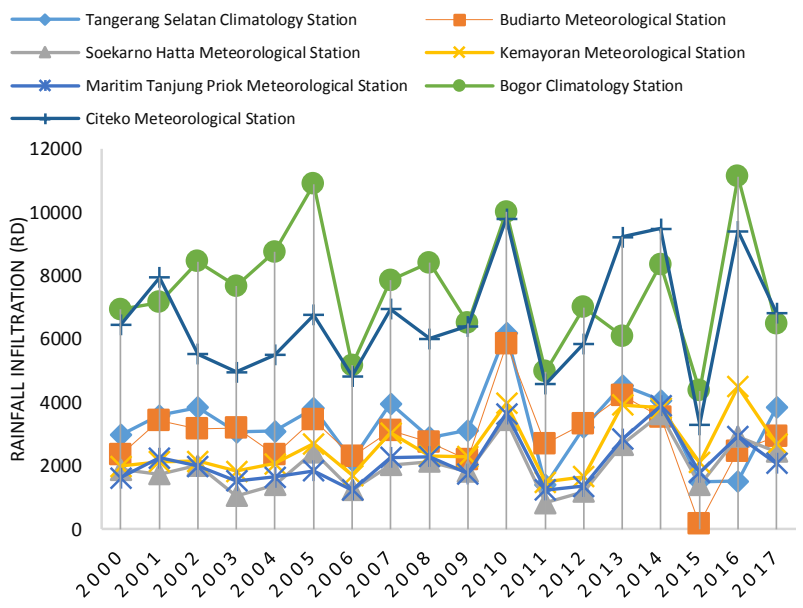

Fig 3. Trend of Rainfall Infiltration in seven weather stations in 2000-2017

The study area is dominated by moderate (2500$3500)$ and very large ( $>5500) \mathrm{RD}$ value. It can be seen from Fig 4 that moderate $\mathrm{RD}$ values dominate the downstream area while very large $\mathrm{RD}$ values dominate the upstream area. The large $\mathrm{RD}$ value in the upstream area is influenced by the amount of rainfall recorded at the Bogor Climatology Station and the Citeko Meteorological Station.

Table 2. Rainfall Infiltration (RD) value in the study area

\begin{tabular}{cccrc}
\hline No & $\begin{array}{c}\text { RD Value } \\
(\mathbf{m m})\end{array}$ & $\begin{array}{c}\text { Inf. } \\
\text { Code }\end{array}$ & Area (Ha) & $\begin{array}{c}\text { Area } \\
\mathbf{( \% )}\end{array}$ \\
\hline 1 & $<2500$ & a & $39.183,59$ & 8,84 \\
$\mathbf{2}$ & $\mathbf{2 5 0 0 - 3 5 0 0}$ & b & $\mathbf{1 5 3 . 5 0 5 , 0 3}$ & $\mathbf{3 4 , 6 3}$ \\
3 & $3500-4500$ & c & $56.368,27$ & 12,72 \\
4 & $4500-5500$ & d & $62.585,98$ & 14,12 \\
$\mathbf{5}$ & $>\mathbf{5 5 0 0}$ & e & $\mathbf{1 3 1 . 6 7 1 , 6 3}$ & $\mathbf{2 9 , 7 0}$ \\
\hline \multicolumn{5}{c}{ Total } \\
\end{tabular}

\subsection{Slope}

In this study, the slope data was obtained from ALOS DSM data processing. The ALOS DSM produced very good results, specifically compared to other freely available DSMs [8].

Infiltration process is influenced by slope conditions. The more flat the level of slope, the higher the rate of infiltration. The low percent of the slope will slow down the runoff rate while increasing the potential for infiltration. Slope data in Table 4 shows that in the study area almost $70 \%$ is an area with flat slopes $(<8 \%)$.

Table 3. Slope conditions in the study area

\begin{tabular}{|c|c|c|c|c|}
\hline No & $\begin{array}{c}\text { Slope } \\
(\%)\end{array}$ & $\begin{array}{l}\text { Inf. } \\
\text { Code }\end{array}$ & Area (Ha) & Area (\%) \\
\hline 1 & $<8$ & $\mathbf{a}$ & $310.006,07$ & 69,93 \\
\hline 2 & $8-15$ & $\mathrm{~b}$ & $45.395,17$ & 10,24 \\
\hline 3 & $15-25$ & c & $35.244,45$ & 7,95 \\
\hline 4 & $25-40$ & d & $26.876,71$ & 6,06 \\
\hline 5 & $>40$ & $\mathrm{e}$ & $25.792,10$ & 5,82 \\
\hline \multicolumn{3}{|c|}{ Total } & $443.314,49$ & 100 \\
\hline
\end{tabular}

\subsection{Soil Type}

Table 4. Soil Infiltration in study area

\begin{tabular}{cccrc}
\hline No & $\begin{array}{c}\text { Permeability } \\
(\mathbf{C m} / \mathbf{J a m})\end{array}$ & $\begin{array}{c}\text { Inf. } \\
\text { Code }\end{array}$ & Area (Ha) & $\begin{array}{c}\text { Area } \\
\mathbf{( \% )}\end{array}$ \\
\hline 1 & $>12,7$ & a & $2.299,17$ & 0,52 \\
2 & $6,3-12,7$ & b & $87.529,84$ & 19,74 \\
$\mathbf{3}$ & $\mathbf{2 , 0}-\mathbf{6 , 3}$ & c & $\mathbf{2 0 7 . 6 5 7 , 1 6}$ & $\mathbf{4 6 , 8 4}$ \\
4 & $0,5-2,0$ & d & $145.828,33$ & 32,90 \\
5 & $<0,5$ & e & - & - \\
\hline & Total & & $443.314,49$ & 100 \\
\hline
\end{tabular}

The soil type data was obtained from the Report of Detailed Flood Handling Preparation Plan in Jabodetabekjur. The report presents Soil Hydrology Group map that is divided into four classes based on U.S. Soil Conservation Service. The soil hydrological group data in the report was developed from the 1: 250.000 scale land system data which is one of the RePPProT products. RePPProT data is the landform map in Indonesia that classifies landscapes based on 
interdependence between agroclimate factor, rock type, topography, soil, hydrological conditions and organism [9].

\subsection{Criticality analysis of the catchment area}

The criticality level of the catchment area can be obtained by comparing the potential infiltration value with the actual infiltration value. The potential infiltration value was obtained by overlaying the Rainfall Infiltration map, Slope Infiltration map and Soil Infiltration maps. While the actual infiltration value obtained from land use map.

Table 5. Potential infiltration in the study area

\begin{tabular}{ccrr}
\hline No & $\begin{array}{c}\text { Potential } \\
\text { Infiltration }\end{array}$ & Area (Ha) & Area (\%) \\
\hline 1 & Very High & - & - \\
2 & High & $114.815,80$ & 25,90 \\
3 & Moderate & $236.383,06$ & 53,32 \\
4 & Low & $72.937,39$ & 16,45 \\
5 & Very Low & $19.178,24$ & 4,33 \\
\hline & Total & $443.314,49$ & 100 \\
\hline
\end{tabular}

Based on the potential infiltration map, most of the study areas have potential infiltration with moderate levels scattered throughout the area, especially in the middle area. The potential infiltration with high levels is in the downstream area while the potential infiltration with very low levels is in the upstream area.
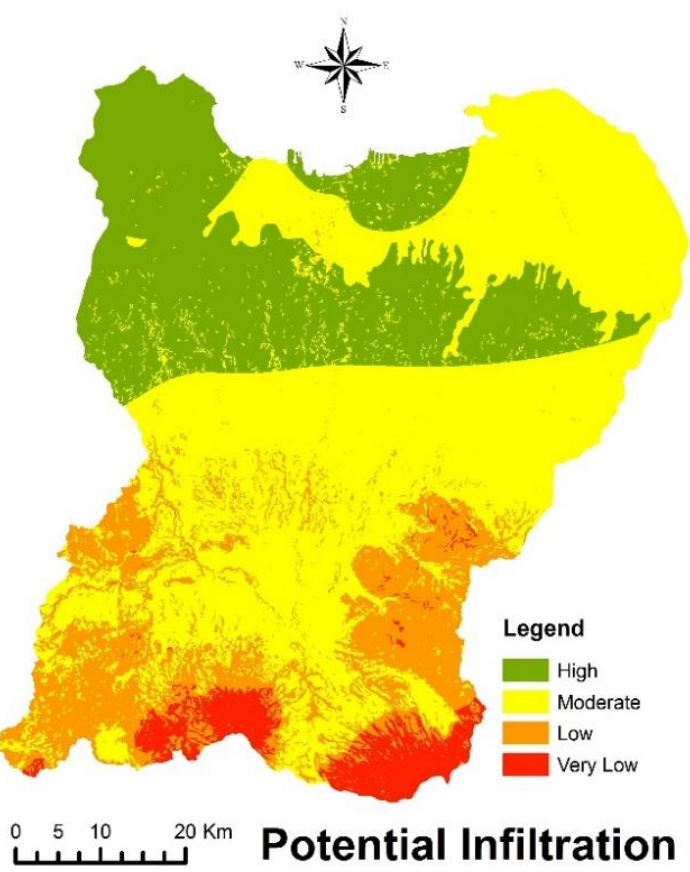

Fig 4. Potential Infiltration map

Table 6. Criticality level of the catchment area in 2000, 2009 and 2017

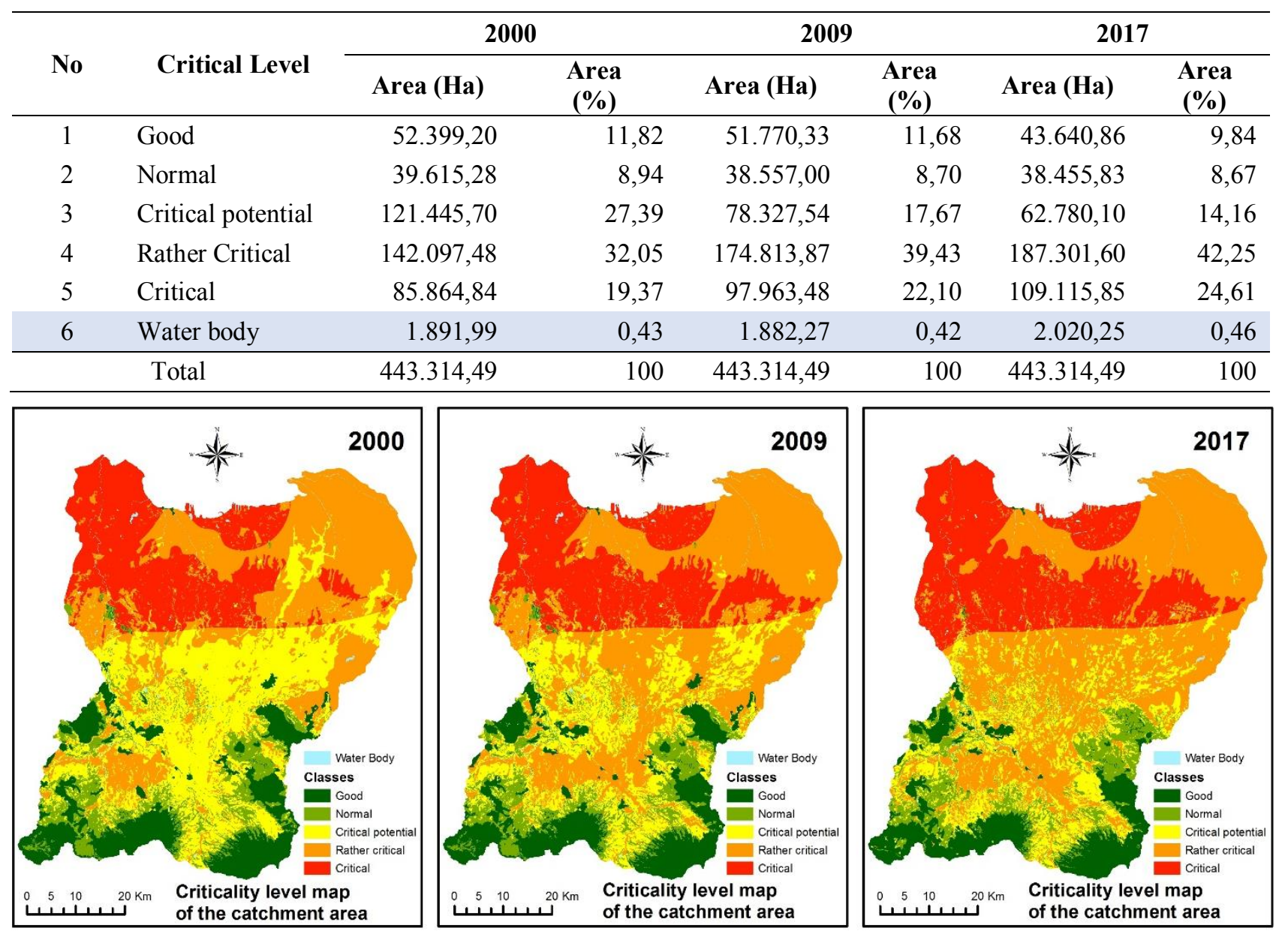

Fig. 5. Criticality level map of the catchment area in 2000, 2009 and 2017 
There are six criticality levels of the catchment area according to the Regulation of Minister of Forestry No. P.32/Menhut-II/2009. However, in this study, there are only five criticality levels of the catchment area, the catchment area with "very critical" level is not available. It is because soil infiltration data used in this study only have four classes viz., fast (a), rather fast (b), moderate (c) and rather slow (d). This analysis will provide better results if using more accurate soil data through ground measurement and soil permeability tests.

The results showed that the catchment area with "good" and "normal" conditions did not change significantly from 2009 until 2017. This condition occurs because the level of potential infiltration in that area is "low" and "very low", so the area is not affected by land use changes. It needs to be discussed further because these conditions tend to occur in the upstream area considering that upstream areas usually have high rainfall and large slopes, which makes infiltration potential tends to be "low" and "very low".

The catchment area with "critical potential" level decreased significantly i.e., $58.665 \mathrm{Ha}$ from 2002 to 2017, while the catchment area with "rather critical" level increased significantly i.e., 45.204 Ha. In addition, the catchment area with "critical" level also increased by $23.251 \mathrm{Ha}$. The increased of catchment areas with "rather critical" and "critical" levels along with the increased of built up area from 2000 to 2017.

Based on the administrative boundaries, the catchment area with "rather critical" and "critical" level increased significantly in Bekasi Regency, Bekasi City, Bogor Regency, Bogor City, Depok City, Tangerang Regency, South Tangerang City. These areas have evolved as the most favorite supporting areas, including for dormitory functions and manufacturing industrial. This is supported by the availability of land at a lower price when compared to areas closer to Jakarta.

The criticality level of the catchment area of three watersheds, viz., Cisadane, Ciliwung, Bekasi, have significantly increased. This explains that the entire area of Jakarta is flood-prone areas because of watershed conditions in the western region (Cisadane Watershed), eastern region (Bekasi Watershed) and central region (Ciliwung Watershed) are increasingly critical.

\section{Conclusion}

The results showed that the largest land use change in eight watersheds that flowed into Jakarta bay, in the period 2000-2017, was the change of dryland farming into built up areas. Based on the analysis, it can be concluded that land use changes mainly due to urban growth has a significant effect on the criticality level of catchment area. In the future, it is necessary to do research on trends and patterns of urban growth in the study area to improve policy development related to regional management.

\section{References}

1 BPS Provinsi DKI Jakarta, DKI Jakarta Dalam Angka Tahun 2018. 2018.

2 P. A. Bhat, M. ul Shafiq, A. A. Mir, and P. Ahmed, "Urban sprawl and its impact on landuse/land cover dynamics of Dehradun City, India," Int. J. Sustain. Built Environ., vol. 6, no. 2, pp. 513-521, 2017.

3 H. M. Mosammam, J. T. Nia, H. Khani, A. Teymouri, and M. Kazemi, "Monitoring land use change and measuring urban sprawl based on its spatial forms: The case of Qom city," Egypt. J. Remote Sens. Sp. Sci., vol. 20, no. 1, pp. 103-116, 2017.

4 L. Dong, L. Xiong, U. Lall, and J. Wang, "The effects of land use change and precipitation change on direct runoff in Wei River watershed, China," Water Sci. Technol., vol. 71, no. 2, pp. 289-295, 2015.

5 Kementerian Kehutanan, Laporan Penyusunan Rencana Detil Penanganan Banjir Di Wilayah Jabodetabekjur. Bogor, 2013.

6 Kementerian Kehutanan, Peraturan Menteri Kehutanan Republik Indonesia No: P.32/MenhutII/2009 tentang Tata Cara Penyusunan Rencana Teknik Rehabilitasi Hutan Dan Lahan Daerah Aliran Sungai (RTkRHL-DAS). Jakarta, 2009.

7 H. Winarso, D. Hudalah, and T. Firman, "Peri-urban transformation in the Jakarta metropolitan area," Habitat Int., vol. 49, pp. 221-229, 2015.

8 U. Alganci, B. Besol, and E. Sertel, "Accuracy Assessment of Different Digital Surface Models," ISPRS Int. J. Geo-Information, vol. 7, no. 3, p. 114, 2018.

9 Nurwadjedi, "Klasifikasi Bentuk Lahan Semi Detil (Skala 1:50.000/1:25.000) Hasil Pengembangan Peta Reppprot Skala 1:250.000," Globe, vol. 2, no. 2, pp. 72-83, 2000. 